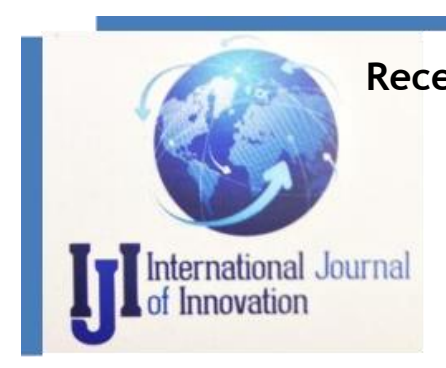

Received on October 20, 2018 / Approved on February 05, 2019

Responsible Editor: Priscila Rezende da Costa

Evaluation Process: Double Blind Review

E-ISSN: 2318-9975

doi> https://doi.org/10.5585/iji.v7i3.347

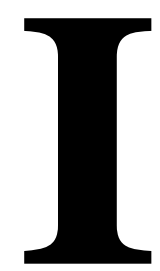

\title{
NVESTIGATING THE KEY FACTORS INFLUENCING THE USE OF ONLINE SOCIAL NETWORKS IN PUBLIC SECTOR CONTEXT IN THE UAE
}

\author{
${ }^{1}$ Ali Ameen \\ ${ }^{2}$ Hamad Almari \\ ${ }^{3}$ Osama Isaac \\ ${ }^{4}$ Fathey Mohammed
}

\section{ABSTRACT}

During the past decade, usage of online social network sites has grown dramatically rivaling search engines as the most visited Internet site. The intensive literature review reveals the existing of several studies that have been done on the field of Online Social Network (OSN), but there is a lack of research that deals with usage in the context of public sector organizations. This study aims to employ structural equation modeling via AMOS to analyze 401 valid questionnaires for assessing a model which is proposed based on Unified Theory of Acceptance and Use of Technology (UTAUT) to identify the factors affecting the use of OSN among employees of a public sector organization in the UAE. The proposed model examines the influence of four factors; performance, effort, social influence, and facilitating conditions on the actual use of OSN. Results indicated that all these factors (as independent variables) significantly predicted the actual usage of OSN with various percentages. Our work improved the insights on the online social networking usage in the context of public sector organizations.

Keywords: Unified Theory of Acceptance and Use of Technology. Online Social Networks. Public sector. UAE. Structural Equation Modeling.

Cite it like this:

Ameen, A., Almari, H., Isaac, O., Mohammed, F. (2019). Investigating the key factors influencing the use of online social networks in public sector context in the UAE. International Journal of Innovation, 7(3), 392-411. http://dx.doi.org/10.5585/iji.v7i3.347.

${ }^{1}$ Lincoln University College, Malaysia. Orcid: https://orcid.org/0000-0002-0303-9854. E-mail: ali.ameen@aol.com.

${ }^{2}$ Lincoln University College, Malaysia. E-mail: almarri_hamad@hotmail.com.

${ }^{3}$ Lincoln University College, Malaysia. Orcid: https://orcid.org/0000-0002-9852-3429. E-mail: osama2isaac@gmail.com.

${ }^{4}$ School of Computing, Universiti Utara Malaysia (UUM), Malaysia. E-mail: fathey.m.ye@gmail.com.

Int. J. Innov., São Paulo, v. 7, n. 3, pp. 392 - 411, September/ December. 2019. 


\section{Introduction}

Over recent years, online social networks (OSN) (also known as social networking services, social networking sites, social media, social media sites, social media platforms) turns in to one of the technology applications of interest, which, in turn, constitutes a phenomenon that remains under debate (Cocosila \& Igonor, 2015). OSN has become increasingly among the fast-growing internet platforms. In the literature, there are studies which link the internet and OSN to organization performance (Wang \& Hou, 2003; Chen, 2008), and others examine how internet platforms improve knowledge acquisition, task efficiency, communication quality, and decision quality in organizations (Isaac et al., 2016). The growth number of OSN users worldwide (such as Facebook, Twitter, WhatsApp, and Linkedln) needs initiatives and investigations to clarify and understand how organizations benefit from such platforms. Extant sources (Arab Social Media Report, 2015 ;Ameen \& Ahmad, 2011) indicate that OSN in the Arab world are perceived as having numerous positive aspects that enhance the quality of life of individuals, business profitability, and governmental interaction with the public.

As organizations around the world struggle to keep pace with emerging technology, changes in Information Technology (IT) grows substantially and itself becomes a driver of further change (Kassim, Ramayah, \& Kurnia, 2012). These changes are considered as one of the most salient and active factors influencing employees and organizations today. The public sector is among the main segments affected by the growth of IT. Online and internet technology applications and services have rapidly become indispensable in the daily life of most individuals and significantly impacted every facet of operations in organizations (Greengard, 2015; Annunziata, 2013;Mutahar et al., 2018). Such applications have also become an essential platform for knowledge management systems that improve knowledge acquisition, task efficiency, communication quality, and decision quality (Mukred, M. Yusof, Mokhtar, \& Abdul Manap, 2016).

Comparison of the number of active accounts on the top social networks to the population shows that the United Arab Emirates (UAE) ranked first with a social network usage penetration of 99 percent (see Figure 1) (Statista, 2017), indicating a huge opportunity be exploited in both public and private sectors to improve professional practice, personal development, and quality of working life (Al-Obthani \& Ameen, 2018).

Tourism is an important economic activity in most countries around the world. As well as its direct economic impact, the industry has significant indirect and induced impacts. The total contribution of the tourism sector to the UAE's GDP was AED 159.1 billion (USD 43.3 billion) which is 12.1 per cent of GDP. It is forecast to rise by 4.9 per cent per annum to AED 264.5 billion (USD 72 billion) which would be 12.4 per cent of GDP in 2027 (Government.ae 2018).

The Tourism Development \& Investment Company (TDIC) is the master developer of major tourism cultural and residential destinations in Abu Dhabi. TDIC was created to be the dedicated tourism asset management and development in order to drive the investment, growth and development of the Emirate's tourism sector. However, TDIC faces the challenges of promotion and attracting visitors from all over the world.

The adoption of OSN is considered to be quite important for improving the status of tourism (Milano, Baggio et al. 2011, Zeng and Gerritsen 2014, Matikiti, Mpinganjira et al. 2017). However, there is a lack of studies investigating OSN use effects on the tourism industry in UAE.

Further, good governance goes beyond the frameworks, policies and procedures built into organization structure; it needs to be instilled into the daily attitudes and activities of employees. Thus, this study examines the use of OSN in the context of tourism industry from the perspective of employees' attitude. Mainly, this study 
targets the employees of TDIC, a public organization in Abu Dhabi. It aims to investigate the influence of performance expectancy, effort expectancy, social influence, and facilitating conditions on the actual usage of OSN in the TDIC in Abu Dhabi.

Fig. 1. Active social network penetration

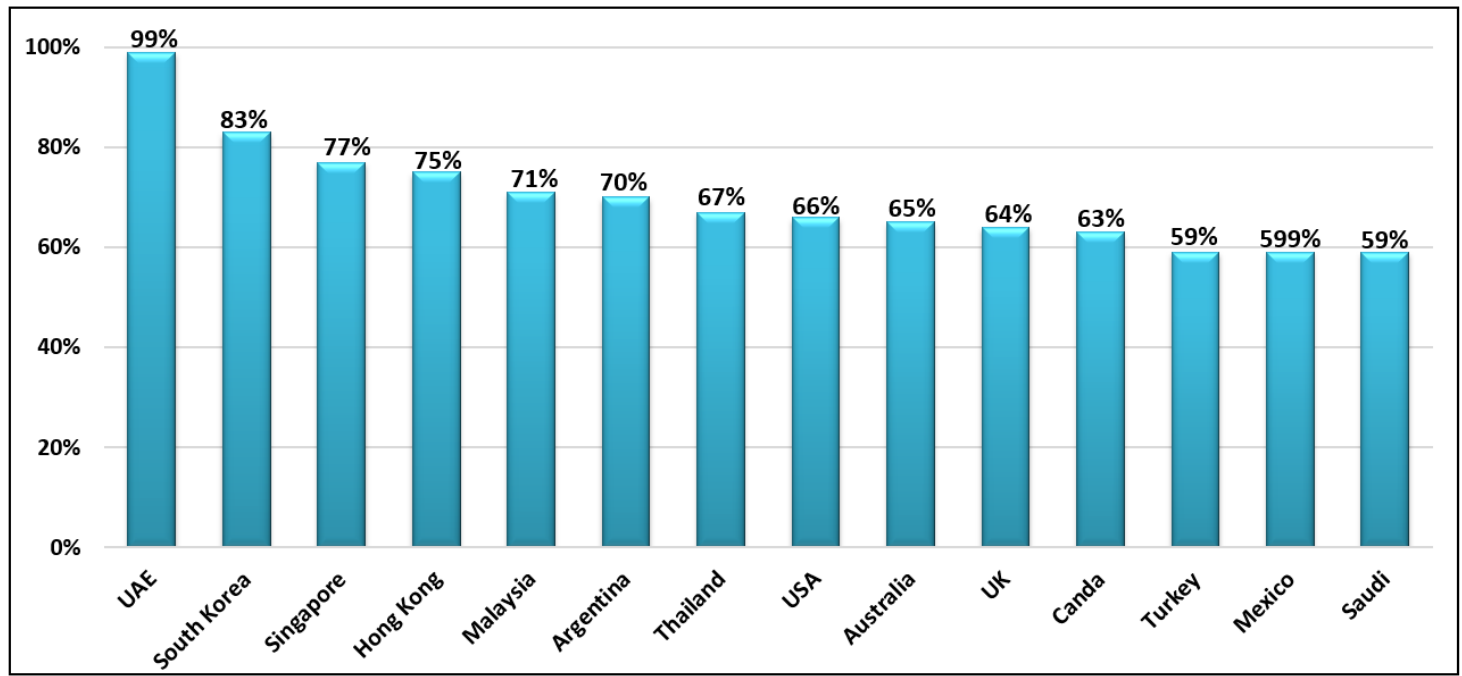

Source: (Statista, 2017)

\section{Why using UTAUT?}

UTAUT is the most suitable model for conducting this research, investigating the key influence factors of online social network use in public sector employees in the UAE. UTAUT was developed by Venkatesh et al., (2003) to explain computer usage behaviour, has achieved wide acceptance and been validated by numerous empirical studies as an accurate predictor of system usage and acceptance. UTAUT has unified 8 theories and models by bringing together a range of theoretical frameworks and ideas; Theory of Reasoned Action (TRA) (Ajzen \& Fishbein, 1980), Theory of Planned Behavior (TPB) (Ajzen, 1985), Technology Acceptance Model (TAM) (Davis, 1989), Social Cognitive Theory (SCT) (Bandura, 1986), Combined TAM \& TPB (C-TAM-TPB) (Todd \& Taylor, 1995), Diffusion of Innovation Theory (DOI) (Rogers, 2003), Motivational Model (MM) (J.Vallerand, 1997), Model of PC Utilization (MPCU) (Chang \& Cheung, 2001).

\section{Literature Review}

\subsection{Performance Expectancy (PE)}

Performance expectancy refers to the degree to which an individual believes using the system will help him/her to attain gains in job performance (Venkatesh, Morris, Davis, \& Davis, 2003b). Many studies have proven that performance expectancy or perceived usefulness plays a major role in the context of information systems (IS) (Zhou, Lu, \& Wang, 2010; Venkatesh, Thong, Chan, Hu, \& Brown, 2011; Ramayah, 2006). Other studies claim that the higher the performance expectancy, the higher the actual system usage (Zhou, Lu, \& Wang, 2010; Al-Qeisi, Dennis, Alamanos, \& Jayawardhena, 2014; Faaeq, Alqasa, \& AlMatari, 2014; Wu, Tao, \& Yang, 2007). This finding is echoed by other results which found a positive relationship between performance expectancy and usage behavior (Al-Gahtani, Hubona, \& Wang, 2007; Tan \& Lau, 2016; Raman \& Don, 2013; Moghawemi, Salleh, Zhao, \& Mattila, 
2012; Raman et al., 2014; Datta, 2011; Lin \& Anol, 2008; Ramayah, Ignatius, \& Aafaqi, 2005). However, several investigations (Lian, 2015; Yueh, Huang, \& Chang, 2015; Faraliza, Noor, Azmi, \& Ramalingam, 2014; Singeh, Abrizah, \& Karim, 2013) found that usage behavior was not influenced by performance expectancy. This research argues that the more employees in the public sector in UAE believe that online social networks are useful in their job and increases their productivity, the more they use the online social networks. Therefore, the following hypothesis is proposed:

H1: Performance expectancy positively affects online social network usage in the context of tourism industry.

\subsection{Effort Expectancy (EE)}

As it was defined by Venkatesh et al., (2003), effort expectancy is the degree of ease associated with the use of the system. It is one of the fundamental antecedent factors of technology usage and adoption (Mutahar et al., 2016; Seppo Pahnila, 2011; Ramayah \& Lo, 2007). Many investigations in different contexts and technological applications have emphasized such relationship (Im, Hong, \& Kang, 2011; Fang, 2014; Venkatesh, Thong, Chan, Hu, \& Brown, 2011; Boonsawat \& T.Naennab, 2014; EscobarRodríguez \& Carvajal-Trujillo, 2014; ChiaLin Hsu, Chen, Lin, Chang, \& Hsieh, 2014). Martins, Oliveira, and Popovič (2014) indicated that there is a positive relationship between effort expectancy and system usage in the context of internet banking. By contrast, some researchers found that effort expectancy does not predict usage behavior (Guo, 2015; Zhou, 2008; Zhou, Lu, \& Wang, 2010; Toh, 2013; Yang, 2013; Ayankunle Adegbite Taiwo, Ahmad Kamil Mahmood, 2012). This research argues that the more employees in the public sector in UAE find that online social networks easy to use, flexible to interact with, and understandable, the more they use the online social networks. Therefore, the following hypothesis is proposed:
H2: Effort expectancy positively influences online social network usage in the context of tourism industry.

\subsection{Social Influence (SI)}

Social influence is broadly described as the degree to which an individual perceives that important others believe he or she should use the new system (Venkatesh et al., 2003b). The social influence factor is substantial in the context of technology success (Martins et al., 2014). According to Venkatesh, Thong, and Xu (2012), in the context of information systems usage, a positive relationship exists between social influence and usage behavior. This claim that social influence appears to have a positive effect on usage behavior is supported by several previous research (AbuShanab \& Pearson, 2007; Gonzalez, Sharma, \& Galletta, 2012; Umak, Polancic, \& Hericko, 2010; Martins, Oliveira, \& Popovič, 2014; Escobar-Rodríguez \& Carvajal-Trujillo, 2014; Wang, 2005; Hendarman \& Tjakraatmadja, 2012). However, other studies did not find such effect (Nysveen \& Pedersen, 2014; Nassuora, 2013; Faaeq, Alqasa, \& AlMatari, 2014; Addo, 2014; Faraliza, Noor, Azmi, \& Ramalingam, 2014). This research argues that the more that supervisor, colleagues, close friends, and family of the employees in the public sector in UAE think that they the employees should use the online social networks, the more the employees use the online social networks. Therefore, the following hypothesis is proposed:

H3: Social influence has a positive effect on online social network usage in the context of tourism industry.

\subsection{Facilitating Conditions (FC)}

According to (Venkatesh et al., 2003b), facilitating conditions are is the degree to which an individual believes organizational and technical infrastructure support the use of the system. Facilitating conditions are essential for individuals to use the system 
(Guo, 2015). To guarantee that the technology is utilized fully, appropriate introduction and back-up are required before an organization can expect its employees to adopt any innovations (AlMaamari et al., 2018). Raman \& Don, (2013) showed that facilitating conditions had a positive influence on usage behavior within the context of learning management software in Malaysia. This finding is in line with other research that confirmed that facilitating conditions can predict usage behavior (Guo, 2015; Moghawemi, Salleh, Zhao, \& Mattila, 2012; Ameen \& Ahmad, 2013). However, contrasting studies revealed facilitating conditions do not influence usage behavior (Lian, 2015; Yueh, Huang, \& Chang, 2015; Martins, Oliveira, \& Popovič, 2014; Fang, 2014; Singeh, Abrizah, \& Karim, 2013; Singeh, Abrizah, \& Karim, 2013). This research argues that the more hardware, software, and knowledge are available and accessible in the public sector organizations in UAE, the more the employees use the online social networks. Therefore, the following hypothesis is proposed:

H4: Facilitating conditions positively influence online social network usage in the context of tourism industry.

\subsection{Actual Usage (USE)}

Actual usage refers to the degree and manner in which users utilize the capabilities of a system. Actual usage relates to the amount, frequency, nature, appropriateness, extent, and purpose of use (DeLone \& McLean, 2016). Kim et al. (2007) suggested actual usage reflects the usage frequency of the technology and usage times. Actual use is defined as the consumption of an IS or its output described in terms of actual or selfreported usage (Petter \& McLean, 2009). Actual usage is considered one of the core constructs in the IS field, and literature is full investigations wherein actual usage is used in numerous contexts and applications because it is the ultimate goal of any technology or application (Ameen \& Ahmad, 2013a; Aldholay, Isaac, Abdullah, \& Ramayah, 2018).

\section{Research Methodology}

\subsection{Proposed Conceptual Model}

The relationships between the constructs hypothesized in the conceptual model have been adapted from relevant literature. Figure 2 shows the proposed model containing performance expectancy, effort expectancy, social influence, and facilitating conditions to predict actual usage. These relationships are taken from Venkatesh, Thong, and $\mathrm{Xu}$ (2016). The said model examines the relationship between the constructs among employees in the TDIC of Abu Dhabi in the UAE. Four hypotheses are tested with the suggested conceptual framework.

Fig. 2 Proposed conceptual framework

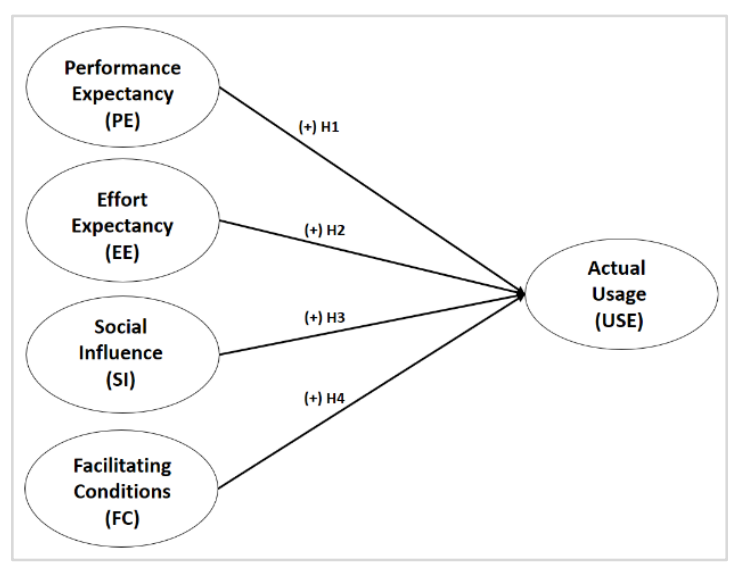

\subsection{Research Instruments}

Developing the instrument for this study involved a 17-item questionnaire applying a multi-item Likert scale based on the information systems literature (Lee, Yoon, \& Lee, 2009). Constructs were measured using a Likert scale recommended in the previous studies (Isaac, Abdullah, Ramayah, \& Mutahar, 2017; Ameen \& Ahmad, 2014) with 5 being "Strongly Agree" and 1 being "Strongly Disagree." Because the respondents were Arabic speakers, questionnaires had to be translated from English to Arabic in a precise manner. Thus, a back translation was applied, which is a procedure used widely in cross-cultural surveys (Brislin, 
1970; Ameen \& Ahmad, 2013a). Extant research was used to validate the measurement of the variables in this study as shown in Appendix A. The number of items for each construct is estimated based on guidelines of Hayduk and Littvay (2012) who recommended the use of a few optimal items.

\subsection{Data Collection}

Data were collected by conducting self-administered distribution of questionnaires to employees within TDIC from July to November 2017. A total of 750 questionnaires were distributed, and 443 were returned, among which 401 were considered suitable for the analysis. According to Tabachnick and Fidell (2012) and Krejcie and Morgan (1970) the sample size was sufficient. Compared with relevant literature, the $59.06 \%$ response rate of this study is considered highly satisfactory (Baruch \& Holtom, 2008; Cable \& Derue, 2002). This study used a personally administered questionnaire (inperson) for data collection. Overall the average response rates for this technique is $62.4 \%$ (Baruch \& Holtom, 2008), because this technique can motivate respondent and doubts can be clarified (Sekaran \& Bougie, 2012).

Excluded questionnaires totaled to 42 , including 26 cases with missing data for more than $15 \%$ of the questions, 5 cases as outliers, and 11 cases with straight lining. Table 1 represents the demographic profile of respondents based on the valid questionnaires.

Table 1: Summary of the demographic profile of respondents

\begin{tabular}{l|lll}
\hline & & $\begin{array}{l}\text { Frequen } \\
\text { cy }\end{array}$ & $\begin{array}{l}\text { Percentage } \\
(\%)\end{array}$ \\
\hline Gender & Male & 293 & 73.1 \\
& Female & 108 & 26.9 \\
Age & less than & 14 & 3.5 \\
& 20 & & \\
& $20-29$ & 108 & 26.9 \\
& $30-39$ & 208 & 51.9 \\
\hline
\end{tabular}

\begin{tabular}{l|lll}
\hline \multirow{5}{*}{ Education } & $\begin{array}{l}40-49 \\
50 \text { and }\end{array}$ & 51 & 12.7 \\
above & & 5.0 \\
& $\begin{array}{l}\text { Secondar } \\
\text { y School }\end{array}$ & 43 & 10.7 \\
& $\begin{array}{l}\text { Diploma } \\
\text { Bachelor' }\end{array}$ & 21 & 5.2 \\
& $\begin{array}{l}\text { Bat } \\
\text { s }\end{array}$ & 72.6 \\
Marital & Master's & 39 & 9.7 \\
Status & PhD/DB & 7 & 1.7 \\
A & Single & 100 & 24.0 \\
& Married & 285 & 71.1 \\
& Divorced & 9 & 2.2 \\
Widowed & 7 & 1.7 \\
\hline
\end{tabular}

\section{Data Analysis and Results}

Structural Equation Modeling (SEM) was selected for data analyzing in this study, because it offers simultaneous analysis that leads to more accurate estimates (Isaac, Abdullah, Ramayah, \& Mutahar, 2017).

\subsection{Descriptive analysis}

Table 3 lists the values of the mean $(M$, with maximum value of 5 ) and standard deviation (SD) as follows: performance expectancy $(M=3.405$ and SD $=1.025$ ) indicates the respondents agreed that OSN use benefitted their jobs, helped in their daily life, increased their productivity, and improved their performance. Effort expectancy $(M=3.395$ and $S D=1.037$ ) suggested the respondents agreed that OSN were easy to use, flexible to interact with, clear, and understandable. Social influence $(M=$ 3.259 and $S D=0.996$ ) implied that the respondents agreed that supervisors, colleagues, close friends, and family think that they should use OSN. Facilitating conditions $(M=3.333$ and $S D=1.091)$ signify the respondents agreed that they have the hardware, software, knowledge, and skills necessary to use the OSN. Actual usage $(M=3.201$ and $S D=0.969)$ denotes the respondents agreed that they use 
regularly OSN, they prefer communication through OSN, and they promote the use of OSN to their colleagues.

\subsection{Measurement Model Assessment and Confirmatory Factor Analysis (CFA)}

As shown in Table 2 , all goodnessof-fit indices surpassed acceptance levels as recommended by previous research, thereby indicating that the measurement model displayed a good fit with the data collected. The total fit indices reveal the chi-square is not significant ( $p$-value should be > 0.5). Despite the nonsignificant chi-square, the model still fits because the chi-square statistic nearly always rejects the model when large samples are used (Bentler \& G.Bonnet, 1980; Jöreskog \& Sörbom, 1993). Note that the chi-square is sensitive to sample size > 200 (Byrne, 2010), and the sample size for this study is 401 . Therefore, we could proceed to evaluate the psychometric properties of the measurement model in terms of construct and indicator reliability, and convergent and discriminant validities.

Table 2: Goodness-of-fit indices for the measurement model

\begin{tabular}{|c|c|c|c|c|}
\hline Fit Index & Cited & Admissibility & Result & Fit (Yes/No) \\
\hline$x^{2}$ & & & 110.560 & \\
\hline DF & & & 94 & \\
\hline$P$ value & & $>.05$ & .000 & No \\
\hline$X^{2} / D F$ & (Kline, 2010) & $1.00-5.00$ & 1.176 & Yes \\
\hline RMSEA & (Steiger, 1990) & $<.08$ & .021 & Yes \\
\hline SRMR & $\begin{array}{c}\text { (Hu \& Bentler, } \\
\text { 1999) }\end{array}$ & $<.08$ & .031 & Yes \\
\hline GFI & $\begin{array}{c}\text { (Jöreskog \& } \\
\text { Sörbom, 1998) }\end{array}$ & $>.90$ & .967 & Yes \\
\hline AGFI & $\begin{array}{c}\text { (Jöreskog \& } \\
\text { Sörbom, 1998) }\end{array}$ & $>.80$ & .952 & Yes \\
\hline $\mathrm{NFI}$ & $\begin{array}{c}\text { (Bentler \& } \\
\text { G.Bonnet, 1980) }\end{array}$ & $>.80$ & .980 & Yes \\
\hline PNFI & $\begin{array}{c}\text { (Bentler \& } \\
\text { G.Bonnet, 1980) }\end{array}$ & $>.05$ & .768 & Yes \\
\hline IFI & (Bollen, 1990) & $>.90$ & .997 & Yes \\
\hline TLI & $\begin{array}{c}\text { (Tucker \& Lewis, } \\
1973 \text { ) }\end{array}$ & $>.90$ & .996 & Yes \\
\hline CFI & (Byrne, 2010) & $>.90$ & .997 & Yes \\
\hline PGFI & $\begin{array}{c}\text { (James, Muliak, \& } \\
\text { Brett, 1982) }\end{array}$ & $>.50$ & .668 & Yes \\
\hline
\end{tabular}

Note: $\mathrm{X}^{2}=$ Chi Square, $\mathrm{DF}=$ Degree of freedom, CFI = Comparative-fit-index, RMSEA = Root mean square error of approximation, $\mathrm{SRMR}=$ Standardized root mean square residual, GFI

$=$ Goodness-of-fit, NFI = Normed fit index, AGFI =Adjusted goodness of fit index, IFI = Increment fit index, , TLI = Tucker-Lewis coefficient index, PNFI = Parsimony normed fit index.

- The indexes in bold are recommended because they are frequently reported in the literature (Awang, 2014) 
Fig. 3: Result of confirmatory factor analysis (CFA)

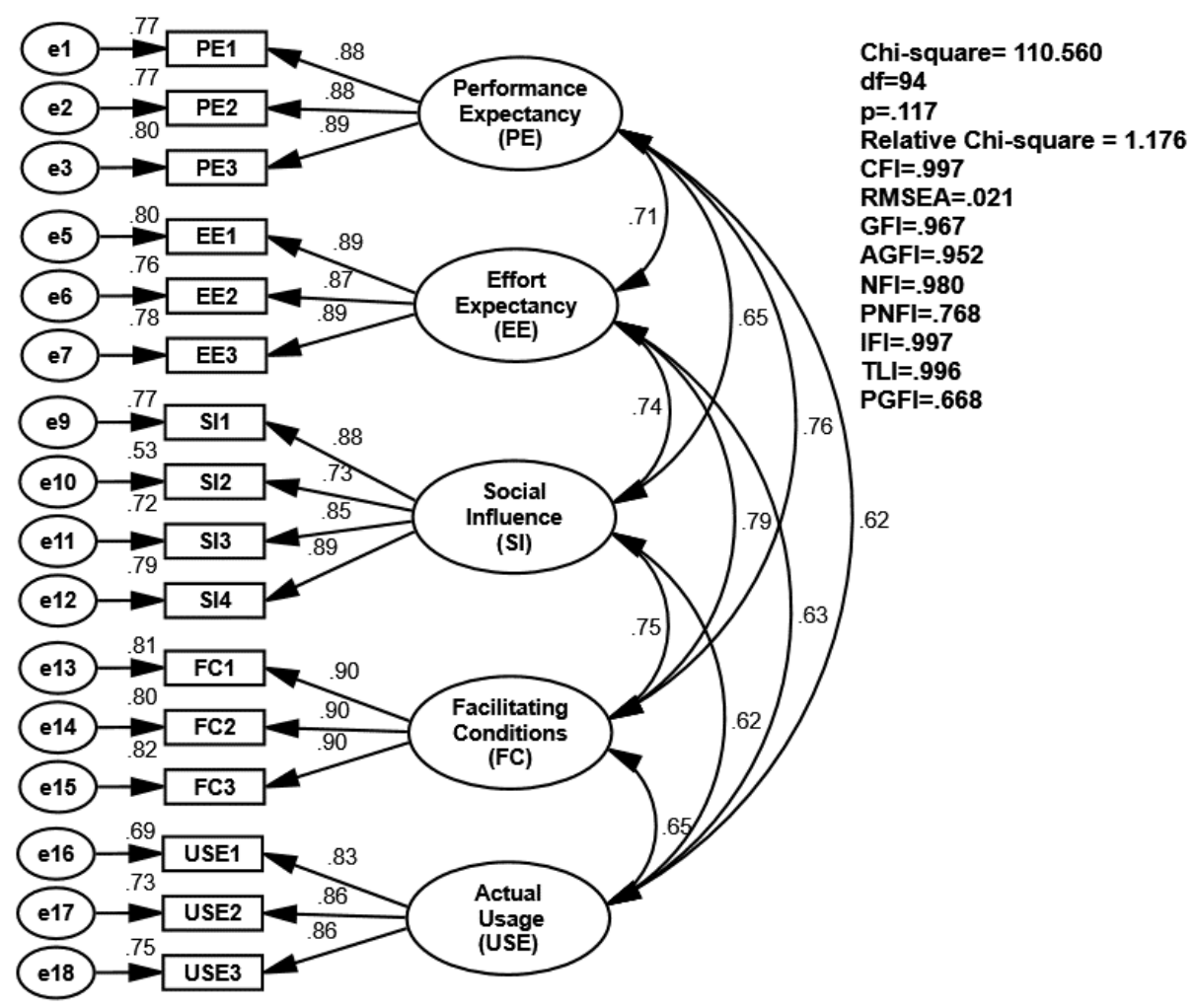

As regards to construct reliability, the results show all Cronbach's alpha coefficients are bigger than the suggested level of 0.7 (Kannana \& Tan, 2005; Nunnally \& Bernstein, 1994). Furthermore, all values of the composite reliability (CR) were greater than the recommended value of 0.7 (Kline, 2010; Gefen, Straub, \& Boudreau, 2000). This result confirms that measurements of all construct are reliable (Table 3). Furthermore, to measure the indicator reliability, factor loadings were checked (J. F. J. Hair, Hult, Ringle, \&
Sarstedt, 2014). The loadings for all items surpassed the suggested value of 0.5 except item PE4, which was removed because of the low loading, thus the indicator reliability is fulfilled. Moreover, to examine the convergent validity, average variance extracted (AVE) criterion was applied. Results showed that all AVE values are greater than the suggested value of 0.50 (J. F. Hair, Black, Babin, \& Anderson, 2010). Therefore, sufficient convergent validity was demonstrated successfully (Table 3 ).

Table 3: Measurement assessment

\begin{tabular}{|c|c|c|c|c|c|c|c|}
\hline Constructs & Item & $\begin{array}{c}\text { Loading } \\
(>0.5)\end{array}$ & $M$ & $S D$ & $\begin{array}{c}\alpha \\
(>0.7)\end{array}$ & $\begin{array}{c}C R \\
(>0.7)\end{array}$ & $\begin{array}{c}A V E \\
(>0.5)\end{array}$ \\
\hline Performance & PE1 & 0.88 & \multirow{3}{*}{3.405} & \multirow{3}{*}{1.025} & \multirow{3}{*}{0.914} & \multirow{3}{*}{0.914} & \multirow{3}{*}{0.781} \\
\hline \multirow[t]{2}{*}{ Expectancy $(P E)$} & PE2 & 0.88 & & & & & \\
\hline & $\begin{array}{l}\text { PE3 } \\
\text { PE4 }\end{array}$ & $\begin{array}{c}0.89 \\
\text { Deleted }\end{array}$ & & & & & \\
\hline \multirow{3}{*}{$\begin{array}{c}\text { Effort Expectancy } \\
(E E)\end{array}$} & EE1 & 0.89 & \multirow{3}{*}{3.395} & \multirow{3}{*}{1.037} & \multirow{3}{*}{0.914} & \multirow{3}{*}{0.914} & \multirow{3}{*}{0.781} \\
\hline & EE2 & 0.87 & & & & & \\
\hline & EE3 & 0.89 & & & & & \\
\hline \multirow[t]{3}{*}{ Social Influence (SI) } & SI1 & 0.88 & \multirow{3}{*}{3.259} & \multirow{3}{*}{0.996} & \multirow{3}{*}{0.903} & \multirow{3}{*}{0.904} & \multirow{3}{*}{0.703} \\
\hline & $\mathrm{SI} 2$ & 0.73 & & & & & \\
\hline & SI3 & 0.85 & & & & & \\
\hline
\end{tabular}




\begin{tabular}{c|ccccccc}
\hline & SI & 0.89 & & & & & \\
Facilitating & & & & & & & \\
Conditions (FC) & FC1 & 0.90 & & & & & \\
& FC2 & 0.90 & 3.333 & 1.091 & 0.927 & 0.927 & 0.808 \\
Actual Usage (USE) & FC3 & 0.90 & & & & & \\
& USE1 & 0.83 & & & & & \\
& USE2 & 0.86 & 3.201 & 0.969 & 0.886 & 0.887 & 0.723 \\
& USE3 & 0.86 & & & & & \\
\hline
\end{tabular}

Note: $M=$ Mean, $S D=$ Standard deviation, $A V E=$ Average variance extracted, $C R=$ Composite reliability, $a=$ Cronbach's alpha.

- Key: PE: performance expectancy, EE: effort expectancy, SI: social influence, FC: facilitating conditions, USE: actual usage

Results for discriminant validity shows that the constructs are strongly related to their particular indicators (Table 4) (Fornell \& Larcker, 1981; Chin, 1998), hence indicating good discriminant validity (J. F. J. Hair et al., 2014). Further, the correlation among exogenous constructs equals < 0.85 (Awang, 2014). Therefore, the discriminant validity of all constructs is achieved.

Table 4: Discriminant validity assessment

\begin{tabular}{c|cccccc}
\hline & Factors & 1 & 2 & 3 & 4 & 3 \\
\cline { 2 - 7 } 1 & & FC & PE & EE & SI & USE \\
2 & FC & $\mathbf{0 . 8 9 9}$ & & & & \\
3 & PE & 0.760 & $\mathbf{0 . 8 8 4}$ & & & \\
4 & EE & 0.786 & 0.707 & $\mathbf{0 . 8 8 4}$ & & \\
5 & SI & 0.747 & 0.655 & 0.738 & $\mathbf{0 . 8 3 8}$ & \\
\hline
\end{tabular}

Note: Diagonals represent the square root of the average variance extracted while the other entries represent the correlations.

Key: PE: performance expectancy, EE: effort expectancy, SI: social influence, FC: facilitating conditions, USE: actual usage.

\subsection{Structural Model Assessment}

The goodness-of-fit of the structural model was comparable to the previous CFA measurement model. In this structural model, the values were recorded as $\mathrm{X}^{2} / \mathrm{df}=1.176, \mathrm{CFI}=0.997$, and RMSEA $=0.021$. These fit indices provide indication of acceptable fit among the hypothesized model and observed data (Byrne, 2010). Thus, path coefficients of the structural model could now be examined. 
Fig. 4: Structural Model Results

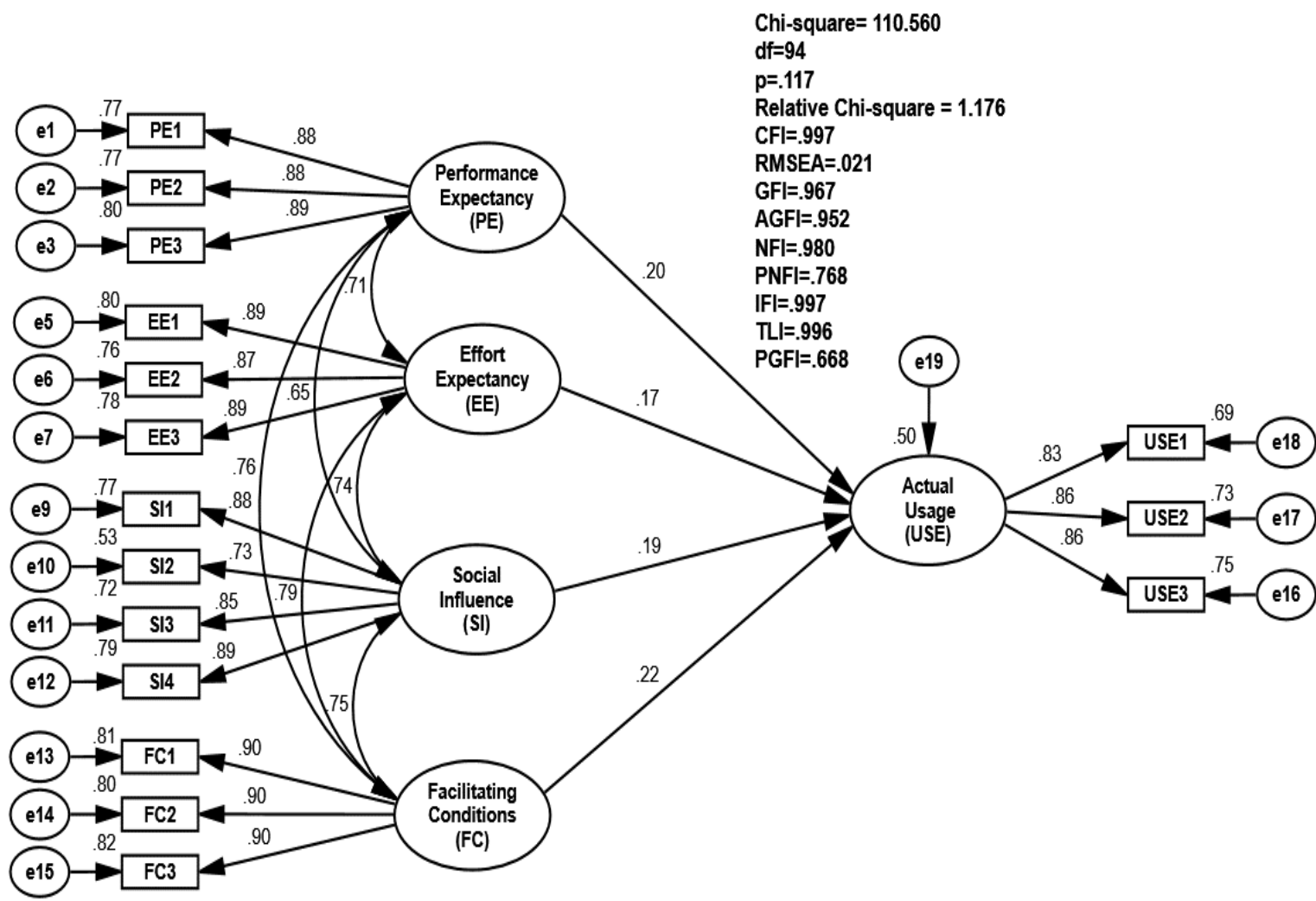

\subsubsection{Direct Hypotheses Tests}

The hypotheses were tested using SEM via AMOS (Fig. 3). The structural model assessment results (shown in Table 5) provide indication of the hypotheses tests, so four out of the four hypotheses of this study being supported. With the results of Performance expectancy (

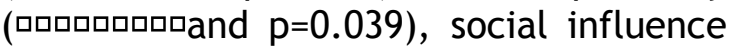

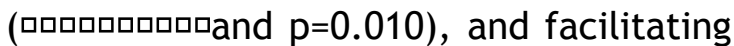
conditions ( $\mathrm{H} 2, \mathrm{H} 3$, and $\mathrm{H} 4$ are supported. These results showed that all factors have a positive impact on actual usage of OSN. Furthermore, the path coefficients' values indicate the strengths of the relationship between independent and dependent variables, and the direct effects of facilitating conditions on actual usage of OSN is stronger than those of the other independent variables.

Table 5: Structural path analysis results

\begin{tabular}{ccccccccc}
\hline \hline Hypothesis & $\begin{array}{c}\text { Dependent } \\
\text { variables }\end{array}$ & $\begin{array}{c}\text { Independent } \\
\text { variables }\end{array}$ & $\begin{array}{c}\text { Estimate B } \\
\text { (path } \\
\text { coefficient) }\end{array}$ & S.E & $\begin{array}{c}\text { C.R } \\
\text { (t- } \\
\text { value) }\end{array}$ & $\begin{array}{c}\text { p- } \\
\text { value }\end{array}$ & Decision \\
\hline $\boldsymbol{H} 1$ & USE & $<---$ & PE & .20 & .059 & 2.749 & 0.006 & Supported \\
$H \mathbf{2}$ & USE & $<---$ & EE & .17 & .072 & 2.063 & 0.039 & Supported \\
$\mathbf{H 3}$ & USE & $<---$ & SI & .19 & .062 & 2.571 & 0.010 & Supported \\
$\mathbf{H 4}$ & USE & $<---$ & FC & .22 & .075 & 2.386 & 0.017 & Supported \\
\hline \hline
\end{tabular}

05, S.E $=$ Standard error, $C . R=$ Critical ratio

Key: PE: performance expectancy, EE: effort expectancy, SI: social influence, FC:

facilitating conditions, USE: actual usage 
4.3.2 Coefficient of Determination $\mathbf{R}^{2}$ : The Variance Explained

The $\mathrm{R}^{2}$ from the structural model showed all $R^{2}$ values are sufficiently high such that the model can fulfill a satisfactory level of explanatory power (Urbach \& Ahlemann, 2010) (see Table 6)

Table 6: Coefficient of determination result $\mathrm{R}^{2}$

\begin{tabular}{cccccc}
\hline \hline $\begin{array}{c}\text { Exogenous } \\
\text { construct }\end{array}$ & $\begin{array}{c}\text { Endogenou } \\
\text { s construct }\end{array}$ & $\mathrm{R}^{2}$ & $\begin{array}{c}\text { Cohen } \\
(1988 \mathrm{~b})\end{array}$ & Chin (1998) & $\begin{array}{c}\text { Hair et al. } \\
\text { (2013) }\end{array}$ \\
\hline $\begin{array}{c}\text { PE, EE, SI, } \\
\text { and FC }\end{array}$ & USE & .50 & Substantial & Moderate & Moderate \\
\hline \hline
\end{tabular}

Key: PE: performance expectancy, EE: effort expectancy, SI: social influence, FC: facilitating conditions, USE: actual usage.

\section{Discussion}

This study proposed a model to improve the understanding of the role of performance expectancy and effort expectancy along with the impact of society and facilitating conditions in predicting the actual use of OSN among employees of the TDIC in Abu Dhabi. The results found that performance expectancy has a positive effect on the actual usage of OSN among respondents. This findings are supported by previous studies (Chang, 2013; Toh, 2013). This implies the fact that the more the user perceived OSN as useful for improvements in work, daily life, user productivity, and performance, the more likely he utilizes OSN regularly and employs them as communication platforms, which makes user more willing to promote OSN to his/her colleagues. Likewise, results showed that effort expectancy has a positive effect on actual usage of OSN among respondents. This outcome is supported by previous studies (Martins et al., 2014; Nysveen \& Pedersen, 2014; Ameen, Almulla, Ali, Al-shibami, \& Ghosh, 2018). This result implies the fact that the more user perceived OSN easy to use, flexible to interact with, and clear and understandable to engage with, the more likely he regularly uses OSN.

In addition, social influence was found to have a positive effect on the actual usage of OSN among respondents, which is consistent with the outcomes of previous studies (Gonzalez et al., 2012; Lian, 2015). This result is explained by the fact that the more supervisors promote the use of OSN among colleagues surrounding the employee, the more likely the employee use OSN and employ them in his work.

Finally, facilitating conditions also was found to have a positive influence on the actual usage of OSN among respondents. This finding is consistent with previous studies (Umak, Polancic, \& Hericko, 2010; Aldholay, Isaac, Abdullah, Alrajawy, \& Nusari, 2018). This implies that the more the organization is well equipped, dedicates resources to provide necessary hardware and software to use OSN, and provides training and guidelines for its employees to ensure they have the necessary knowledge and skills to use the technology, the more likely the employees utilize OSN.

\section{Implications, Limitations and Future Directions}

Unified theory of acceptance and use of technology (UTAUT) has played a vital role in the understanding of what affects the acceptance and use of different types of technology applications. This work successfully validated the UTAUT in a new context, namely, in the usage of OSN among employees in a public organization in the UAE. However, the 
examined relationships may be influenced by moderating variables such as experience, age and gender, thus testing these effects is suggested in the future studies in the same context.

The research prescribed here has implications for the improved understanding of the links between the various significant dimensions related to social networking as a technology innovation in the tourism sector. The results should be of interest to industry players, policymakers, and researchers. Given the fashionableness and reputation of OSN and mobile technology, it seems likely that OSN can enhance the promotion of the UAE in general and Abu Dhabi, in particular, to attract visitors from around the world. Therefore, the tourism authority of Abu Dhabi and government policymakers are advised to integrate OSN into their operating procedures. Such positive views are also reported in the literature (Amato et al., 2018). This study has the limitation of being conducted in only one organization of the public sector in the UAE, and thus its results should be taken with caution.

We live in a technology-driven world. Change is constant and overwhelming, raising the compelling call for continuous research effort regarding the use and adoption of OSN to leverage potential customers' engagement in their various applications. Such engagement will no doubt improve the delivery of information in an innovative way and accommodate new directions in attracting numerous visitors (He, He, \& Xu, 2018).

\section{Conclusion}

While the government institutions of the United Arab Emirates are ahead of its regional counterparts in terms of performance, the government is striving to enhance its public organizations' productivity (Global Innovation Index, 2016). The application of innovative ICT platforms and Internet in the tourist sector make it easier, spacious, and more efficient.

The findings of this study could be considered as one of the initiatives toward achieving this aim. The main objective of this research was to determine factors influencing the use of OSN within the TDIC in Abu Dhabi. Despite various constraints to the study, the outcomes have been encouraging, as this work managed to shed some light on a new perspective. This research proposed a model which identifies performance expectancy, effort expectancy, social influence, and facilitating conditions as independent variables and actual usage of OSN as the dependent variable. Findings revealed the four independent variables significantly explain $50 \%$ of actual usage of OSN. The implications of this study were deliberated and some directions for future research were suggested.

\section{Appendix A}

\begin{tabular}{|c|c|c|}
\hline Variable & Measure & Source \\
\hline $\begin{array}{l}\text { Performan } \\
\text { ce } \\
\text { Expectancy } \\
\text { (PE) }\end{array}$ & $\begin{array}{l}\text { PE1: I find online social networks useful in my job. } \\
\text { PE2: I find online social networks useful in my daily life. } \\
\text { PE3: Using online social networks increases my } \\
\text { productivity. } \\
\text { PE4: Using online social networks improves my } \\
\text { performance. }\end{array}$ & $\begin{array}{l}\text { (Martins et al., 2014) } \\
\text { (Cheng, Liu, Qian, \& Song, } \\
\text { 2013) (Moghawemi et al., } \\
\text { 2012) (Lian, 2015) }\end{array}$ \\
\hline $\begin{array}{l}\text { Effort } \\
\text { Expectancy } \\
\text { (EE) }\end{array}$ & $\begin{array}{l}\text { EE1: I find the online social networks easy to use. } \\
\text { EE2: I find the online social networks flexible to interact } \\
\text { with. }\end{array}$ & $\begin{array}{l}\text { (Tomás Escobar-Rodríguez, } \\
\text { Carvajal-Trujillo, \& Monge- } \\
\text { Lozano, 2014) (Cheng et } \\
\text { al., 2013) }\end{array}$ \\
\hline
\end{tabular}


EE3: My interaction with online social networks is clear and understandable.

Social Influence

(SI)

Facilitating Conditions (FC)

Actual Usage (USE)
SI1: My supervisor thinks that I should use the online social networks.

SI2: My colleagues think that I should use the online social networks.

SI3: My close friends think that I should use the online social networks.

SI4: My family thinks that I should use the online social networks.

FC1: I have the hardware and software necessary to use the online social networks.

FC2: I have the knowledge necessary to use the online social networks.

FC3: I have the skills necessary to use the online social networks.

USE1: I regularly use online social networks.

USE2: I prefer communication through online social networks.

USE3: I promote the use of online social networks to my colleagues.
(Venkatesh et al., 2012)

(Cheng, 2011) (Brown, Dennis, \& Venkatesh, 2010)

(Moghawemi et al., 2012)

(Gu, Lee, \& Suh, 2009)

(Lian, 2015)

(Nistor, Lerche, Weinberger, Ceobanu, \& Heymann, 2014) (Lin, 2007)

\section{References}

AbuShanab, E., \& Pearson, J. M. (2007). Internet banking in Jordan: The unified theory of acceptance and use of technology (UTAUT) perspective. Journal of Systems and Information Technology, 9(1), 78-97. http://doi.org/10.1108/132872607108177 00

A Hayduk, L., \& Littvay, L. (2012). Should researchers use single indicators, best indicators, or multiple indicators in structural equation models? BMC Medical Research Methodology, 12(1), 159.

Addo, H. (2014). Using the UTAUT model to analyze students' ICT adoption. International Journal of Education and Development Using Information and Communication Technology, 10(3), 75-86.
Ajzen, I. (1985). From intentions to actions: A theory of planned behavior. In Kuhl (Ed.), Action control: From cognition to behavior (pp. 11-39). Berlin, Heidelber, New York: Springer-Verlag.

Ajzen, I., \& Fishbein, M. A. (1980). Understanding Attitudes and Predicting Social Behaviour (1st ed.). New York: Pearson.

Al-Gahtani, S. S., Hubona, G. S., \& Wang, J. (2007). Information technology (IT) in Saudi Arabia: Culture and the acceptance and use of IT. Information \& Management, 44(8), 681-691. http://doi.org/10.1016/j.im.2007.09.002

Al-Maamari, Q. A., Muhammed Kassim, R.-N., Raju, V., Al-Tahitah, A., Ameen, A., \& Abdulrab, M. (2018). Factors Affecting Individual Readiness for Change: A Conceptual Framework. International 
Journal of Management and Human Science, 2(1), 13-18.

Al-Obthani, F., \& Ameen, A. (2018). Towards Customized Smart Government Quality Model. International Journal of Software Engineering \& Applications, $\quad$ 9(2), 41-50. http://doi.org/10.5121/ijsea.2018.9204

Al-Qeisi, K., Dennis, C., Alamanos, E., \& Jayawardhena, C. (2014). Website design quality and usage behavior: Unified Theory of Acceptance and Use of Technology. Journal of Business Research, 67(11), 2282-2290. http://doi.org/10.1016/j.jbusres.2014.06 .016

Aldholay, A. H., Isaac, O., Abdullah, Z., Alrajawy, I., \& Nusari, M. (2018). THE ROLE OF COMPATIBILITY AS A MODERATING VARIABLE IN THE INFORMATION SYSTEM SUCCESS MODEL: THE CONTEXT OF ONLINE LEARNING USAGE. International Journal of Management and Human Science (IJMHS), 2(1), 9-15.

Aldholay, A. H., Isaac, O., Abdullah, Z., \& Ramayah, T. (2018). The Role of Transformational Leadership as a Mediating Variable in DeLone and McLean Information System Success Model: The Context of Online Learning usage in Yemen. Telematics and Informatics. http://doi.org/10.1016/j.tele.2018.03.01 2

Amato, F., Castiglione, A., De Santo, A., Moscato, V., Picariello, A., Persia, F., \& Sperlí, G. (2018). Recognizing human behaviours in online social networks. Computers and Security, 74, 355-370.

http://doi.org/10.1016/j.cose.2017.06.0 02

Ameen, A., \& Ahmad, K. (2011). The Role of Finance Information Systems in anti financial corruptions: A theoretical review. 2011 International Conference on Research and Innovation in Information Systems, 1-6. http://doi.org/10.1109/ICRIIS.2011.61257 25
Ameen, A., \& Ahmad, K. (2013a). A Conceptual Framework of Financial Information Systems to Reduce Corruption. Journal of Theoretical and Applied Information Technology, 54(1), 59-72.

Ameen, A., \& Ahmad, K. (2013b). Proposing Strategy for Utilizing Financial Information Systems in Reducing Corruption. In 3rd International Conference on Research and Innovation in Information Systems - 2013 (ICRIIS'13) (Vol. 2013, pp. 75-80).

Ameen, A., \& Ahmad, K. (2014). A Systematic Strategy for Harnessing Financial Information Systems in Fighting Corruption Electronically. In Knowledge Management International Conference (KMICe) 2014, 12 - 15 August 2014, Malaysia (pp. 12-15). Retrieved from http://www.kmice.cms.net.my/

Ameen, A., Almulla, A., Ali, M., Alshibami, A. H., \& Ghosh, A. (2018). The Impact of Knowledge Sharing on Managing Organizational Change within Abu Dhabi National Oil Organizations. International Journal of Management and Human Science (IJMHS), 2(3), 27-36.

Arab Social Media Report. (2015). Benefits of Social Media usage, Arab Social Media Influencers Summit.

Awang, Z. (2014). Structural Equation Modeling Using AMOS. Shah Alam.Malaysia: University Teknologi MARA Publication Center.

Bandura, A. (1986). Social Foundations of Thought and Action: A Social Cognitive Theory. NJ: Prentice Hall.

Baruch, Y., \& Holtom, B. C. (2008). Survey response rate levels and trends in organizational research. Human Relations, 61(8), 1139-1160. http://doi.org/10.1177/001872670809486 3

Bentler, P. M., \& G.Bonnet, D. (1980). Significance tests and goodness of fit in the analysis of covariance structures. Psychological Bulletin, 88(3), 588-606.

Bollen, K. A. (1990). Overall fit in covariance structure models: Two types of 
sample size effects. Psychological Bulletin, 107(2), 256-259.

Boonsawat, S., \& T.Naennab. (2014). The UTAUT Model For The Study Of Acceptance And Use Of Capability Maturity Model Integration.

Brislin, R. W. (1970). BackTranslation for Cross-Cultural Research. Journal of Cross-Cultural Psychology (Vol. 1).

http://doi.org/10.1177/135910457000100 301

Brown, S. a., Dennis, A. R., \& Venkatesh, V. (2010). Predicting Collaboration Technology Use: Integrating Technology Adoption and Collaboration Research. Journal of Management Information Systems, 27(2), 9-54. http://doi.org/10.2753/MIS07421222270201

Byrne, B. M. (2010). Structural Equation Modeling With AMOS: Basic Concepts, Applications, and Programming (2nd ed.). Routledge.

Chang, C.-C. (2013). Library mobile applications in university libraries. Library $\mathrm{Hi} \quad$ Tech, 31(3), 478-492. http://doi.org/10.1108/LHT-03-20130024

Chang, M., \& Cheung, W. (2001). Determinants of the intention to use Internet/www at work: a confirmatory study. Information and Management, 39 (1) 1-14.

Chen, C. (2008). Study on Application of E-commerce and Organizational Performance in Taiwanese Professional Sports Event Promotion Organizations. The Journal of Human Resource and Adult Learning, 4(1), 66-73.

Cheng, D., Liu, G., Qian, C., \& Song, Y.-F. (2013). Customer Acceptance of Internet Banking : Integrating Trust and Quality with UTAUT Model. IEEE, 1(1), 383388.

Cheng, Y. M. (2011). Antecedents and consequences of e-learning acceptance. Information Systems Journal, 21,

269-299. http://doi.org/10.1111/j.1365-

2575.2010.00356.x

Chin, W. W. (1998a). Issues and opinion on structural equation modeling. MIS Quarterly, 22(1), 7-16.

Chin, W. W. (1998b). The partial least squares approach to structural equation modeling. (pp. 295-358). New Jersey: Lawrence Erlbaum.

Cocosila, M., \& Igonor, A. (2015). How important is the "social " in social networking? A perceived value empirical investigation. Information Technology \& People, 28(2), 366-382. http://doi.org/10.1108/ITP-03-2014-0055

Cohen, J. (1988). Statistical Power Analysis for the Behavioral Sciences (2nd Editio). LawreAssociatesnce Erlbaum.

Datta, P. (2011). A preliminary study of ecommerce adoption in developing countries. Information Systems Journal, 21(1), 3-32. http: //doi.org/10.1111/j.1365-

2575.2009.00344.x

Davis, F. D. (1989). perceived Usefulness, Perceived ease of use, and User Acceptence of inforamtion technology. MIS Quarterly, 13(3), 319-340.

DeLone, W. H., \& McLean, E. R. (2016). Information Systems Success Measurement. Series in Information Technology Management. now Publishers Inc. PO.

Escobar-Rodríguez, T., \& CarvajalTrujillo, E. (2014). Online purchasing tickets for low cost carriers: An application of the unified theory of acceptance and use of technology (UTAUT) model. Tourism Management, 43, 70-88. http://doi.org/10.1016/j.tourman.2014.0 1.017

Escobar-Rodríguez, T., CarvajalTrujillo, E., \& Monge-Lozano, P. (2014). Factors that influence the perceived advantages and relevance of Facebook as a learning tool: An extension of the UTAUT. Australasian Journal of Educational Technology, 30(2), 136-151. http://doi.org/10.14742/ajet.v30i2.585 
Faaeq, M. K., Alqasa, K., \& AlMatari, E. M. (2014). Technology adoption and innovation of E-Government in Republic of Iraq. Asian Social Science, 11(3), 135-145. http://doi.org/10.5539/ass.v11n3p135

Fang, S.-F. (2014). Using UTAUT Model to Explore the User Behavior of ELearning System in a Public Sector. Department of Communications Management.

Faraliza, N., Noor, M., Azmi, A. A. C., \& Ramalingam, L. (2014). The Unified Theory of Acceptance and Use of Technology ( UTAUT ) and the Goods and Service Tax ( GST ) Application System. Research Journal of Applied Sciences, Engineering and Technology, 8(17), 19111916.

Fornell, C., \& Larcker, D. F. (1981). Evaluating structural equation models with unobservable variables and measurement error. Journal of Marketing Research, 18(1), 39-50.

Gefen, D., Straub, D., \& Boudreau, M.-C. (2000). Structural equation modeling and regression: Guidelines for research practice. Communications of the Association for Information Systems, 4(1), 1-79.

Global Innovation Index. (2016). Government institutions effectiveness: Yemen versus Arab countries: Rank among 143 countries, Cornell University, INSEAD, and the World Intellectual Property Organization (WIPO).

Gonzalez, G. C., Sharma, P. N., \& Galletta, D. (2012). Factors Influencing the Planned Adoption of Continuous Monitoring Technology. Journal of Information Systems, 26(2), 53-69. http: / / doi.org/10.2308/isys-50259

Greengard, S. (2015). The Internet of Things. (T. M. Press, Ed.).

Gu, J.-C., Lee, S.-C., \& Suh, Y.-H. (2009). Determinants of behavioral intention to mobile banking. Expert Systems with Applications, 36(9), 1160511616. http://doi.org/10.1016/j.eswa.2009.03.0
Guo, Y. (2015). Moderating Effects of Gender in the Acceptance of Mobile SNS Based on UTAUT Model. International Journal of Smart Home, 9(1), 203-216.

Haddad, A., Ameen, A., \& Mukred, M. (2018). The Impact of Intention of Use on the Success of Big Data Adoption Via Organization Readiness Factor. International Journal of Management and Human Science, 2(1), 43-51.

Hair, J. F., Black, W. C., Babin, B. J., \& Anderson, R. E. (2010). Multivariate Data Analysis. New Jersey.

Hair, J. F. J., Hult, G. T. M., Ringle, C., \& Sarstedt, M. A Primer on Partial Least Squares Structural Equation Modeling (PLS-SEM), 46 Long Range Planning 328 (2014). London: Thousand Oaks:

SAGE. http://doi.org/10.1016/j.lrp.2013.01.002

He, P., He, Y., \& Xu, F. (2018). Evolutionary analysis of sustainable tourism. Annals of Tourism Research, 69(July 2017), 76-89. http://doi.org/10.1016/j.annals.2018.02. 002

Hendarman, A. F., \& Tjakraatmadja, J. H. (2012). Relationship among Soft Skills, Hard Skills, and Innovativeness of Knowledge Workers in the Knowledge Economy Era. Procedia Social and Behavioral Sciences, 52, 35-44. http://doi.org/10.1016/j.sbspro.2012.09. 439

Hsu, C.-L., Chen, M.-C., Lin, Y.-H., Chang, K.-C., \& Hsieh, A.-Y. (2014). Adopting the Extension of UTAUT Model to Investigate the Determinants of e-book Adoption.

Hu, L., \& Bentler, P. M. (1999). Cutoff criteria for fit indexes in covariance structure analysis: Conventional criteria versus new alternatives. Structural Equation Modeling, 6, 1-55.

Im, I., Hong, S., \& Kang, M. S. (2011). An international comparison of technology adoption: adoption Testing the UTAUT model. Information \& Management, $\quad 48(1), \quad$ 1-8. http://doi.org/10.1016/j.im.2010.09.001 
Isaac, O., Abdullah, Z., Ramayah, T., \& Mutahar, A. M. (2017a). Internet usage, user satisfaction, task-technology fit, and performance impact among public sector employees in Yemen. The International Journal of Information and Learning Technology, 34(3), 210-241. http://doi.org/10.1108/IJILT-11-20160051

Isaac, O., Abdullah, Z., Ramayah, T., \& Mutahar, A. M. (2017b). Internet Usage and Net Benefit among Employees Within Government Institutions in Yemen: An Extension of Delone and Mclean Information Systems Success Model (DMISM) with Task-Technology Fit. International Journal of Soft Computing, 12(3), 178-198. http://doi.org/10.3923/ijscomp.2017.178 .198

Isaac, O., Abdullah, Z., Ramayah, T., Mutahar, A. M., \& Alrajawy, I. (2016). Perceived Usefulness, Perceived Ease of Use, Perceived Compatibility, and Net Benefits: an empirical study of internet usage among employees in Yemen. In The 7th International Conference Postgraduate Education (ICPE7) (pp. 899-919). Shah Alam, Malaysia.

J.Vallerand, R. (1997). Toward A Hierarchical Model of Intrinsic and Extrinsic Motivation. Advances in Experimental Social Psychology, 29(1), 271-360.

James, L. R., Muliak, S. A., \& Brett, J. M. (1982). Causal analysis: Models, assumptions and data. Beverly Hills, CA: Sage.

Jöreskog, K., \& Sörbom, D. (1998). LISREL 8: Structural Equation Modeling with the SIMPLIS Command Language. Chicago, IL: Scientific Software International Inc.

Kannana, V. R., \& Tan, K. C. (2005). Just in time, total quality management, and supply chain management: understanding their linkages and impact on business performance. Omega: The International Journal of Management Science, 33(2), 153-162.
Kassim, N. M., Ramayah, T., \& Kurnia, S. (2012). Antecedents and outcomes of human resource information system (HRIS) use. International Journal of Productivity and Performance Management, 61(6), 603-623. http://doi.org/10.1108/174104012112491 84

Kim, H.-W., Chan, H. C., \& Gupta, S. (2007). Value-based Adoption of Mobile Internet: An empirical investigation. Decision Support Systems, 43(1), 111-126. http://doi.org/10.1016/j.dss.2005.05.009

Kline, R. B. (2010). Principles and practice of structural equation modeling (3rd ed.). New York: The Guilford Press.

Krejcie, R. V, \& Morgan, D. W. (1970). Determining sample size for research activities. Educational and Psychological Measurement, 38, 607-610.

Lee, B. C., Yoon, J. O., \& Lee, I. (2009). Learners' acceptance of e-learning in South Korea: Theories and results. Computers and Education, 53(4), 13201329.

http://doi.org/10.1016/j.compedu.2009. 06.014

Lian, J.-W. (2015). Critical factors for cloud based e-invoice service adoption in Taiwan: An empirical study. International Journal of Information Management, 35(1), 98-109. http://doi.org/10.1016/j.ijinfomgt.2014. 10.005

Lin, C.-P., \& Anol, B. (2008). Learning online social support: an investigation of network information technology based on UTAUT. Cyberpsychology \& Behavior: The Impact of the Internet, Multimedia and Virtual Reality on Behavior and Society, 11(3), 268-72.

http: //doi.org/10.1089/cpb.2007.0057

Lin, H. F. (2007). Predicting consumer intentions to shop online: An empirical test of competing theories. Electronic Commerce Research and Applications, 6, 433-442. http://doi.org/10.1016/j.elerap.2007.02. 002 
Martins, C., Oliveira, T., \& Popovič, A. (2014). Understanding the Internet banking adoption: A unified theory of acceptance and use of technology and perceived risk application. International Journal of Information Management, 34(1), 1-13. http://doi.org/10.1016/j.ijinfomgt.2013. 06.002

Moghawemi, S., Mohd Salleh, N. A., Zhao, W., \& Mattila, M. (2012). The entrepreneur's perception on information technology innovation adoption: An empirical analysis of the role of precipitating events on usage behavior. Innovation: Management, Policy and Practice, 14(2), 231-246. http://doi.org/10.5172/impp.2012.14.2.2 31

Moore, G. A. (2006). Crossing the Chasm: Marketing and Selling High-Tech Products to Mainstream Customers.

Mukred, M., M. Yusof, Z., Mokhtar, U. A., \& Abdul Manap, N. (2016). Electronic Records Management System Adoption Readiness Framework for Higher Professional Education Institutions in Yemen. International Journal on Advanced Science, Engineering and Information Technology, 6(6), 804. http://doi.org/10.18517/ijaseit.6.6.1369

Mutahar, A. M., Daud, N. M., Ramayah, T., Putit, L., Isaac, O., \& Alrajawy, I. (2016). The Role of Trialability, Awareness, Perceived Ease of Use, and Perceived Usefulness in Determining the Perceived Value of Using Mobile Banking in Yemen. In The 7th International Conference Postgraduate Education (ICPE7) (pp. 884-898). Shah Alam, Malaysia.

Mutahar, A. M., Daud, N. M., Thurasamy, R., Isaac, O., \& Abdulsalam, R. (2018). The Mediating of Perceived Usefulness and Perceived Ease of Use : The Case of Mobile Banking in Yemen. International Journal of Technology Diffusion, 9(2), 21-40. http://doi.org/10.4018/IJTD.2018040102

Nassuora, A. B. (2012). Students Acceptance of Mobile Learning for Higher
Education in Saudi Arabia. American Academic \& Scholarly Research Journal, 4(2), 1-9. http://doi.org/10.12785/ijlms/010101

Nistor, N., Lerche, T., Weinberger, A., Ceobanu, C., \& Heymann, O. (2014). Towards the integration of culture into the Unified Theory of Acceptance and Use of Technology. British Journal of Educational Technology, 45(1), 36-55. http://doi.org/10.1111/j.1467-

8535.2012.01383.x

Nysveen, H., \& Pedersen, P. E. (2014). Consumer adoption of RFIDenabled services. Applying an extended UTAUT model. Information Systems Frontiers.

http://doi.org/10.1007/s10796-014-95314

Pahnila, S., Siponen, M., \& Zheng, X. (2011). Integrating Habit into UTAUT: The Chinese eBay Case. Pacific Asia Journal of the Association for Information Systems, 3(2), 1-30.

Petter, S., \& McLean, E. R. (2009). A meta-analytic assessment of the DeLone and McLean IS success model: An examination of IS success at the individual level. Information \& Management, 46(3), 159-166.

http://doi.org/10.1016/j.im.2008.12.006

Raman, A., \& Don, Y. (2013). Preservice teachers' acceptance of learning management software: An application of the UTAUT2 model. International Education Studies, 6(7), 157164.

http://doi.org/10.5539/ies.v6n7p157

Raman, A., Don, Y., Khalid, R., Hussin, F., Omar, M. S., \& Ghani, M. (2014). Technology Acceptance on Smart Board among Teachers in Terengganu Using UTAUT Model. Asian Social Science, 10(11).

http://doi.org/10.5539/ass.v10n11p84

Ramayah, T., Ignatius, J., \& Aafaqi, B. (2004). Pc Usage Among Students In A Private Institution Of Higher Learning: The Moderating Role Of Prior Experience. Malaysian Journal of Educators and Education, 20, 131-152. 
Ramayah, T., \& Lo, M.-C. (2007). Impact of shared beliefs on "perceived usefulness" and "ease of use" in the implementation of an enterprise resource planning system. Management Research News, 30(6), 420-431. http://doi.org/10.1108/014091707107519 17

Sekaran, U., \& Bougie, R. (2012). Research Methods for Business: A SkillBuilding Approach (6th ed.). Wiley.

Singeh, F. W., Abrizah, A., \& Karim, N. H. A. (2013). Malaysian authors' acceptance to self-archive in institutional repositories: Towards a unified view. Electronic Library, 31(2), 188-207. http://doi.org/10.1108/026404713113123 75

Statista. (2017). Active social network penetration.

Steiger, J. H. (1990). Structural model evaluation and modification: An interval estimation approach. Multivariate Behavioral Research, 25 (2), 173-180.

Sumak, B., Polancic, G., \& Hericko, M. (2010). An Empirical Study of Virtual Learning Environment Adoption Using UTAUT. 2010 Second International Conference on Mobile, Hybrid, and OnLine Learning, 17-22. http://doi.org/10.1109/eLmL.2010.11

Tabachnick, B. G., \& Fidell, L. S. (2007). Using Multivariate Statistics. PsycCRITIQUES, $28, \quad 980$. http://doi.org/10.1037/022267

Taiwo, A. A., Mahmood, A. K., \& Downe, A. G. (2012). User acceptance of eGovernment: Integrating risk and trust dimensions with UTAUT model. 2012 International Conference on Computer and Information Science, ICCIS 2012 - A Conference of World Engineering, Science and Technology Congress, ESTCON 2012 Conference Proceedings, 1, 109-113. http://doi.org/10.1109/ICCISci.2012.6297 222

Tan, E., \& Leby Lau, J. (2016). Behavioural intention to adopt mobile banking among the millennial generation Article information: Young Consumers,
17(1). $\quad$ http://doi.org/10.1108/YC-072015-00537

Taylor, S., \& Todd, P. A. (1995). Understanding Information Technology Usage: A Test of Competing Models. Information System Research, 6(2), 144176.

Toh, C. H. (2013). Assessing adoption of wikis in a Singapore secondary school: Using the UTAUT model. Proceedings of the 2013 IEEE 63rd Annual Conference International Council for Education Media, ICEM 2013, 1-9. http://doi.org/10.1109/CICEM.2013.6820 158

Tucker, L. R., \& Lewis, C. (1973). A reliability coefficient for maximum likelihood factor analysis. Psychometrika, 38(1), 1-10.

Šumak, B., Polancic, G., \& Hericko, M. (2010). An Empirical Study of Virtual Learning Environment Adoption Using UTAUT. 2010 Second International Conference on Mobile, Hybrid, and OnLine Learning, 17-22. http://doi.org/10.1109/eLmL.2010.11

Urbach, N., \& Ahlemann, F. (2010). Structural Equation Modelling in Information Systems Research Using Partial Least Squares. Journal of Information Technology Theory and Application, 11(2), 5-40.

Venkatesh, V., Morris, M. G., Davis, G. B., \& Davis, F. D. (2003a). User Acceptance of Information Technology: Toward a Unified View. MIS Quarterly, 27(3), 425-478.

Venkatesh, V., Morris, M. G., Davis, G. B., \& Davis, F. D. (2003b). USER ACCEPTANCE OF INFORMATION TECHNOLOGY: TOWARD A UNIFIED VIEW, 27(3), 425-478.

Venkatesh, V., Thong, J. Y. L., Chan, F. K. Y., Hu, P. J.-H., \& Brown, S. a. (2011). Extending the two-stage information systems continuance model: incorporating UTAUT predictors and the role of context. Information Systems Journal, 21(6), 527-555. http://doi.org/10.1111/j.13652575.2011.00373.x 
Venkatesh, V., Thong, J. Y. L., \& $\mathrm{Xu}, \quad$ X. (2012). CONSUMER ACCEPTANCE AND USE OF INFORMATION TECHNOLOGY : EXTENDING THE UNIFIED THEORY OF ACCEPTANCE AND USE OF TECHNOLOGY. MIS Quarterly, 36(1), 157-178.

Venkatesh, V., Thong, J. Y. L., \& $\mathrm{Xu}, \quad \mathrm{X}$. (2016). Unified Theory of Acceptance and Use of Technology: A Synthesis and the Road Ahead. Journal of the Association for Information Systems, 17(5), 328-376.

Wang, C. (2005). A Study of Taiwanese College Teachers' Acceptance of Distance Learning. International Journal of Organizational Innovation, (2), 243-261.

Wang, J., \& Hou, F. (2003). Research on the Relationship between the Internet Usages and the Organizational Performance in the Taiwanese Ecommerce Business Organizations. Informing Science, 17-25.

Wu, Y. L., Tao, Y. H., \& Yang, P. C. (2007). Using UTAUT to explore the behavior of $3 \mathrm{G}$ mobile communication users. IEEM 2007: 2007 IEEE International Conference on Industrial Engineering and Engineering Management, 199-203. http://doi.org/10.1109/IEEM.2007.44191 79

Yang, S. (2013). Understanding Undergraduate Students' Adoption of Mobile Learning Model: A Perspective of the Extended UTAUT2. Journal of Convergence Information Technology, $8(10)$, 969-979. http://doi.org/10.4156/jcit.vol8.issue10. 118

Yueh, H. P., Huang, J. Y., \& Chang, C. (2015). Exploring factors affecting students' continued Wiki use for individual and collaborative learning: An extended UTAUT perspective. Australasian Journal of Educational Technology, 31(1), 16-31.

Zhou, T. (2008). Exploring Mobile User Acceptance Based on UTAUT and Contextual Offering. 2008 International Symposium on Electronic Commerce and Security, 241-245. http://doi.org/10.1109/ISECS.2008.10
Zhou, T., Lu, Y., \& Wang, B. (2010). Integrating TTF and UTAUT to explain mobile banking user adoption. Computers in Human Behavior, 26(4), 760767.

http://doi.org/10.1016/j.chb.2010.01.01 3 tourism.

Government.ae (2018). Travel and

Matikiti, R., M. Mpinganjira and M. Roberts-Lombard (2017). "Social media in tourism: Establishing factors influencing attitudes towards the usage of social networking sites for trip organisation." Acta Commercii 17(1): 1-13.

Milano, R., R. Baggio and R. Piattelli (2011). The effects of online social media on tourism websites. ENTER.

Zeng, B. and R. Gerritsen (2014). "What do we know about social media in tourism? A review." Tourism Management Perspectives 10: 27-36. 